\title{
Identification of leaf-mining insects via DNA recovered from empty mines
}

\author{
Julia J. Mlynarek ${ }^{a \star \dagger}$, Jin-Hong Kim ${ }^{\mathrm{a}}$, and Stephen B. Heard ${ }^{\mathrm{a}}$ \\ ${ }^{a}$ Department of Biology, University of New Brunswick, Fredericton, NB E3B 5A3, Canada \\ *julia.mlynarek@canada.ca \\ ${ }^{\dagger}$ Present address: Harrow Research and Development Centre, Agriculture and Agri-Food Canada, 2585 \\ County Road 20, Harrow, ON N0R 1G0, Canada.
}

\begin{abstract}
We report the development of an improved method for the extraction and amplification of leaf miner DNA recovered from empty mines. Our method is simple, easy to use, and foregoes the timeconsuming task of scraping out mines required by previous methods. We collected leaves with 1- and 2 -day-old vacated mines, cut out and then ground the mined portions, and amplified the mtDNA COI barcode sequence using universal insect primers. We obtained high-quality sequences for $31 \%$ of our empty mines: $20 \%$ yielded sequences associated with a leaf miner species; and an additional $11 \%$ yielded sequences associated with whiteflies, mites, or fungi. Our improved method will facilitate ecological studies determining herbivore community dynamics and agricultural studies for pest monitoring and identification.
\end{abstract}

Key words: herbivory, barcode, molecular

\section{OPEN ACCESS}

Citation: Mlynarek JJ, Kim J-H, and Heard SB. 20 16. Identification of leaf-mining insects via DNA recovered from empty mines. FACETS 1: 217-224. doi:10.1139/ facets-2016-0026

Editor: Vance L Trudeau

Received: June 6, 2016

Accepted: September 8, 2016

Published: November 23, 2016

Copyright: (C) 2016 Mlynarek et al. This work is licensed under a Creative Commons Attribution 4.0 International License (CC BY 4.0), which permits unrestricted use, distribution, and reproduction in any medium, provided the original author(s) and source are credited.

Published by: Canadian Science Publishing

\section{Introduction}

Leaf miners are a diverse group of herbivores, with approximately 10000 species worldwide belonging to at least four insect orders (Coleoptera, Diptera, Hymenoptera, and Lepidoptera; Auerbach et al. 1995). In many natural systems, leaf miners are highly prevalent and can have substantial impacts on their hosts (Raimondo et al. 2003). Furthermore, leaf miners can be major pests in agricultural and horticultural systems, reducing crop production and esthetic value (Hering 1951; Parella and Keil 1984; Raimondo et al. 2003). Some leaf-mining pests are invasive; of these, some represent entirely new taxa for an area, whereas others displace native congeners that they resemble closely (Abe and Tokumara 2008). Thus, accurate identification of leaf-mining species is extremely important, both in natural systems and for the monitoring of actually or potentially invasive species.

However, for a number of reasons, leaf miners can be very difficult to identify. Adults do not associate with their host plants until oviposition; hence, adult collections cannot typically be connected to host plant species. Larvae develop inside leaves (feeding on the parenchyma cells; Connor and Taverner 1997), where they can be inconspicuous for most of their life cycle. Most leaf mines are detected late (i.e., once the mine has become apparent), but by then the larva might have reached its last instar or vacated the mine as an adult. Even if larvae have been collected, they are difficult to identify because they have few easily scored morphological characters (Spencer 1990). Adults can be morphologically identified, but it is logistically difficult to rear enough individuals to obtain large sample sizes, and identification can still be challenging for non-experts because of the difficulty of locating and using identification tools (Derocles et al. 2015). Finally, generalist miners (based on adult morphology) 
may prove to be complexes of cryptic host races (e.g., the holly leaf miner Phytomyza glabricola (Diptera: Agromyzidae; Scheffer and Hawthorne 2007) or cryptic species (J. Mlynarek, personal observation, 2015). These difficulties suggest great value for techniques that could identify leaf miners without depending on morphological characters, especially for mines that have already been vacated.

Molecular techniques for species identification are constantly improving. Sequence-based identification of specimens in-hand is now routine (Joly et al. 2013). Holometabolous insects can be identified by barcoding empty puparia (Mazzanti et al. 2010), and host insects from parasitoids (including leaf miners) can be identified using DNA sequencing from post-emergence pupa or puparia (Hrcek et al. 2011; Condon et al. 2014). Environmental DNA can even be used to simultaneously identify entire communities (e.g., Taberlet et al. 2012). Recently, Derocles et al. (2015) developed a method to amplify DNA from empty leaf mines. They opened mines and scraped the inside of the mine to collect larval skins and frass (which may include sloughed gut cells), and sequenced either the insect barcode (a $658 \mathrm{bp}$ fragment of COI) or a mini-barcode (a $130 \mathrm{bp}$ fragment of COI) from the scrapings. However, their method is laborious, and they had a low success rate of amplification (6\%) for older mines.

We have developed an alternative method for the extraction and amplification of leaf miner DNA from empty mines. Our method is simple and foregoes the time-consuming task of scraping out mines of Derocles et al. (2015) with greater sequencing success.

\section{Methods}

We collected 96 mined leaves of Doellingeria umbellata (Asteraceae) from the University of New Brunswick Woodlot (Fredericton, New Brunswick, Canada; 45.915, -66.648) in July 2015. We chose leaves with "blotch" mines (Fig. 1); these are irregular mines usually $>1 \times 0.5 \mathrm{~cm}$ (i.e., not the narrow tunnels of "serpentine" mines). These are most often associated with miners of the genus Nemorimyza (Diptera: Agromyzidae), but similar blotch mines can be formed on plants in the Asteraceae family by the larvae of Sumitrosis (Coleoptera: Chrysomelidae), Microrhopala (Coleoptera: Chrysomelidae), and Cremastobombycia (Lepidoptera: Gracillariidae). We collected mines that seemed freshly vacated (the mine and the surrounding tissue had not yet dried), or were still occupied by a miner larva, and kept each in its own plastic snap-cap 60 dram vial.

In the laboratory, for mines that were already vacated $(N=8)$, we cut out the mined portion of the leaf with a sterilized scalpel, placed each excised mine into a $1.5 \mathrm{~mL}$ vial, and stored it at $-80^{\circ} \mathrm{C}$ until DNA extraction. For mines with larvae inside $(N=88)$, we held each leaf in a vial with a damp cotton ball, at room temperature under natural light, until the mine was vacated. All the mines were vacated successfully. For 38 mines, we cut out and froze the mined portion of the leaf immediately upon finding it vacated; for a further 50, we held the leaves for two additional days in the vials before cutting out the mined portion.

We extracted genomic DNA (gDNA) from each preserved mine using an acetylmethylammonium bromide (CTAB) protocol for animal tissue (Grosberg et al. 1996). Mined leaf tissue was ground in liquid nitrogen before $\mathrm{CTAB}$ extraction. We used $500 \mu \mathrm{L}$ of $\mathrm{CTAB}$ mix and allowed 12-16 hours for tissue digestion. The concentration of gDNA extracted was measured using Qubit assays with a broad range kit (Thermo Fisher Scientific, Montana, USA). Aliquots of each gDNA sample were prepared for PCR work adjusting their concentrations to $2 \mathrm{ng} / \mu \mathrm{L}$.

We amplified the standard 658 bp barcode region of cytochrome oxidase 1 using Folmer et al.'s (1994) polymerase chain reaction (PCR) primers (forward LCOI1490: 5'-GGTCAACAAATCAT AAAGATATTGG-3'; reverse HCOI2198: 5'-TAAACTTCAGGGTGACCAAAAAATCA-3'; Integrated 


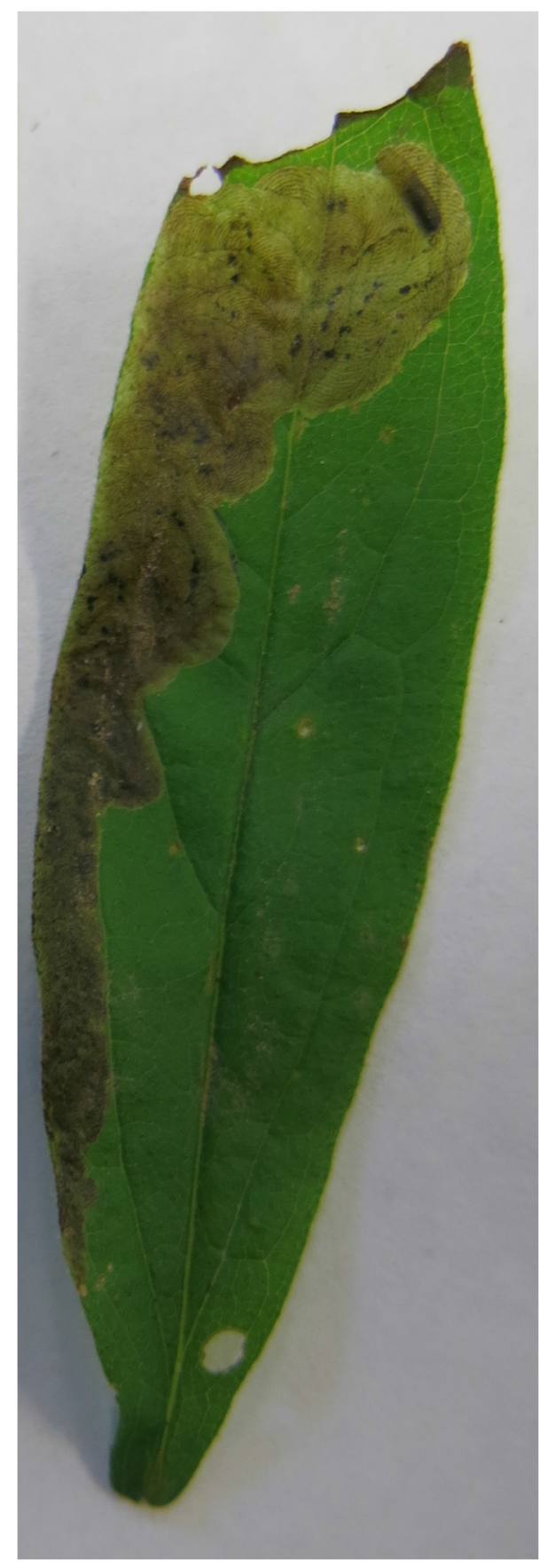

Fig. 1. Blotch leaf mine from Doellingeria umbellata.

DNA Technologies, Coralville, Iowa, USA), which provide near-universal amplification for many insect orders (Pons 2006). Amplification was performed in a $30 \mu \mathrm{L}$ volume with 4 ng DNA, $1 \times$ ThermoPol reaction buffer (New England Biolabs (NEB), Whitby, Ontario, Canada), $0.2 \mathrm{mM}$ dNTPs (NEB), 1× purified BSA (stock is 100×; NEB, cat. no. B9001S) and $2 \mathrm{mM} \mathrm{MgSO}_{4}$ (stock is $100 \mathrm{mM}$; NEB, cat. no. B1003S), $0.5 \mu \mathrm{mol} / \mathrm{L}$ forward and reverse primers, and 1.0 U Taq DNA polymerase (NEB). Thermal cycling conditions were as follows: an initial denaturation at $95^{\circ} \mathrm{C}$ for $5 \mathrm{~min}$, followed by 19 cycles at $95^{\circ} \mathrm{C}$ for $30 \mathrm{~s}$; 
from 45 to $64{ }^{\circ} \mathrm{C}$ with an increment of $1{ }^{\circ} \mathrm{C}$ per cycle for $30 \mathrm{~s} ; 7{ }^{\circ} \mathrm{C}$ for $1 \mathrm{~min}$, followed by 29 cycles at $95^{\circ} \mathrm{C}$ for $30 \mathrm{~s}, 45^{\circ} \mathrm{C}$ for $30 \mathrm{~s}, 72^{\circ} \mathrm{C}$ for $1 \mathrm{~min}$; and a final extension at $72{ }^{\circ} \mathrm{C}$ for $5 \mathrm{~min}$.

We checked successful amplification (or amplicons of the partial COI gene) by running aliquots on $1.5 \%$ agarose gels at $100 \mathrm{~V}$ for $35 \mathrm{~min}$ and checking for bands in the target size (600-700 bp). Some samples showed only faint bands, so we used gel extraction to re-amplify these. We excised 600-700-bp bands with GeneCatcher gel excision pipettor tips (Gel Company, San Francisco, California, USA; cat. no. PKB6.5) and extracted DNA using QIAEX II gel-extraction kits (QIAGEN, Toronto, Ontario, Canada; cat. no. 20051) following the manufacturer's instructions. We sent 32 successfully amplified samples for sequencing to the McGill University and Genome Quebec Innovation Centre (Montreal, Québec, Canada).

We aligned, edited, and trimmed the sequences to a length of $658 \mathrm{bp}$ using ClustalO (Sievers et al. 2011). We performed a nucleotide sequence similarity search using BLASTn (Altschul et al. 1990) and crossreferenced sequences in GenBank (Benson et al. 2011) using BLASTn query (and matched them in the Barcode of Life Data System (BOLD; Rathasingham and Hebert 2013) to appropriate Barcode Index Number (BIN) clusters for identification (Ratnasingham and Hebert 2013), searching all barcode records on BOLD). We tested whether there was a significant difference in the rates of molecular identification of leaf miners between mines vacated in the lab and those collected empty using a Fisher's exact test in R (R Core Team 2013).

\section{Results}

Fourteen samples showed clear bands upon initial amplification, indicating successful amplification. We obtained clear bands for an additional 18 samples following gel extraction and re-amplification. Of these 32 amplified samples, 30 were returned with high-quality sequence data (allowing 658 bp sequence alignment and thus GenBank identification). Nineteen of these matched (99\%-100\% match) to agromyzid leaf miners (Diptera: Agromyzidae): 11 to Nemorimyza posticata and eight to unidentified Agromyzidae sp. (Table 1). Seven sequences matched with the fungus Jaminaea angkoriensis (Basidiomycota: Microstromatales), two with whiteflies (Hemiptera: Aleyrodidae) and two with tydeid mites (Trombidiformes: Tydeidae) (Table 1). All arthropod specimens could be assigned to a BIN in the BOLD database: 11 sequences matched with Nemorimyza posticata, one with Phytomyza sp., seven with unidentified Agromyzidae spp., two with unidentified aleyrodid whiteflies, and two with mites in the genus Tydeus. The seven Jaminaea angkoriensis specimens could not be placed in a BIN because Jaminaea BOLD data because these specimens are a fungus and COI gene is not the barcode gene for fungi.

Amplification success did not depend on the timing of DNA extraction $(P=0.15)$. Two of the eight (25\%) already-vacated mines, four of the $38(11 \%)$ mines that were dissected immediately after being vacated, and 13 of the $50(26 \%)$ mines vacated 2 days prior allowed successful identification of leafmining flies.

\section{Discussion}

Our extraction led to the successful amplification and sequencing of 19 leaf miners from our 96 empty mines (19\%). Our mines were relatively fresh ( $40 \%$ were vacated for a day, $52 \%$ were vacated for just 2 days, with the remainder vacated for intervals that are unknown but likely measured in days at most). While we found no significant difference in amplification success among these categories, Derocles et al. (2015) noted that amplification success declined with time a leaf mine had been empty. We suspect that our amplification success would, similarly, have been lower if we had collected older mines. Time since the DNA was deposited seems to be a major determinant of amplification success in other systems as well (e.g., for mammalian scat, 3 days between deposition and DNA extraction made DNA much more difficult to identify; Santini et al. 2007). Storage conditions between collection 
and extraction can also influence amplification success, as DNA degradation can be minimized by protection from light, preservation in regularly changed $90 \%$ ethanol (vs. $70 \%$ ), and the storage of ethanol-preserved material in a freezer (Zimmermann et al. 2008).

Table 1. Leaf mine collection states $(\mathrm{V}=$ mine vacated in the field, $\mathrm{I}=$ mine dissected immediately in the lab, or $\mathrm{L}=$ mine dissected 2 days after being vacated in the lab), GenBank accession numbers, and identification results in GenBank and BOLD databases for DNA amplified from empty leaf mines with associated BOLD BIN cluster for each sample.

\begin{tabular}{|c|c|c|c|c|c|c|c|}
\hline \multirow[b]{2}{*}{ Sample ID } & \multirow[b]{2}{*}{ State } & \multirow[b]{2}{*}{ Accession \# } & \multicolumn{2}{|c|}{ GenBank } & \multicolumn{3}{|c|}{ BOLD } \\
\hline & & & ID & Similarity (\%) & ID & Similarity (\%) & BIN \\
\hline EM_07 & $\mathrm{V}$ & KX810685 & Aleyrodidae sp. & 99.7 & Aleyrodidae sp. & 99.6 & BOLD:AAZ8499 \\
\hline EM_21 & V & KX810703 & Nemorimyza posticata & 100 & N. posticata & 99.9 & BOLD:AAG9234 \\
\hline EM_23 & $\mathbf{V}$ & KX810676 & Agromyzidae sp. & 100 & Agromyzidae sp. & 100 & BOLD:AAG4743 \\
\hline EM_32 & $\mathrm{L}$ & KX810692 & Jaminaea angkoriensis & 85.1 & J. angkoriensis & 81.6 & NA \\
\hline EM_37 & $\mathbf{L}$ & KX810681 & Agromyzidae sp. & 100 & Agromyzidae sp. & 100 & BOLD:AAG4743 \\
\hline EM_39 & $\mathbf{L}$ & KX810680 & Agromyzidae sp. & 99.8 & Agromyzidae sp. & 99.8 & BOLD:AAG4743 \\
\hline EM_44 & $\mathbf{L}$ & KX810702 & Nemorimyza posticata & 99.8 & N. posticata & 99.5 & BOLD:AAG9234 \\
\hline EM_46 & $\mathbf{L}$ & KX810679 & Agromyzidae sp. & 99.8 & Agromyzidae sp. & 99.8 & BOLD:AAG4743 \\
\hline EM_49 & $\mathbf{I}$ & KX810678 & Agromyzidae sp. & 100 & Phytomyza sp. & 100 & BOLD:AAG4775 \\
\hline EM_50 & $\mathbf{L}$ & KX810701 & Nemorimyza posticata & 99.8 & N. posticata & 99.5 & BOLD:AAG9234 \\
\hline EM_51 & $\mathrm{L}$ & KX810684 & Aleyrodidae sp. & 99.5 & Aleyrodidae sp. & 99.6 & BOLD:AAZ8499 \\
\hline EM_58 & $\mathbf{L}$ & KX810700 & Nemorimyza posticata & 99.5 & N. posticata & 99.4 & BOLD:ACJ0616 \\
\hline EM_61 & $\mathrm{L}$ & KX810705 & Tydeidae sp. & 99.4 & Tydeus sp. & 97.6 & BOLD:AAH0991 \\
\hline EM_67 & I & KX810704 & Tydeidae sp. & 99.4 & Tydeus sp. & 97.6 & BOLD:AAH0991 \\
\hline EM_69 & $\mathbf{I}$ & KX810693 & Nemorimyza posticata & 99.7 & N. posticata & 99.4 & BOLD:AAG9234 \\
\hline EM_72 & $\mathbf{L}$ & KX810698 & Nemorimyza posticata & 99.7 & N. posticata & 99.5 & BOLD:AAG9234 \\
\hline EM_75 & $\mathrm{L}$ & KX810691 & Jaminaea angkoriensis & 91.8 & J. angkoriensis & 84.6 & NA \\
\hline EM_78 & $\mathbf{L}$ & KX810682 & Agromyzidae sp. & 100 & Agromyzidae sp. & 100 & BOLD:AAG4743 \\
\hline EM_86 & $\mathbf{L}$ & KX810697 & Nemorimyza posticata & 99.8 & N. posticata & 99.5 & BOLD:AAG9234 \\
\hline EM_88 & I & KX810687 & Jaminaea angkoriensis & 91.8 & J. angkoriensis & 84.7 & NA \\
\hline EM_89 & I & KX810690 & Jaminaea angkoriensis & 85.1 & J. angkoriensis & 81.7 & NA \\
\hline EM_92 & $\mathbf{L}$ & KX810677 & Agromyzidae sp. & 100 & Agromyzidae sp. & 100 & BOLD:AAG4743 \\
\hline EM_95 & $\mathrm{L}$ & KX810686 & Jaminaea angkoriensis & 91.8 & J.angkoriensis & 84.7 & NA \\
\hline EM_96 & $\mathrm{L}$ & KX810689 & Jaminaea angkoriensis & 85.1 & J. angkoriensis & 82.0 & NA \\
\hline EM_98 & $\mathbf{L}$ & KX810683 & Agromyzidae sp. & 99.8 & Agromyzidae sp. & 99.8 & BOLD:AAG4743 \\
\hline EM_102 & I & KX810696 & Nemorimyza posticata & 99.7 & N. posticata & 99.4 & BOLD:AAG9234 \\
\hline EM_105 & $\mathbf{L}$ & KX810695 & Nemorimyza posticata & 99.8 & N. posticata & 99.5 & BOLD:AAG9234 \\
\hline EM_106 & $\mathrm{L}$ & KX810688 & Jaminaea angkoriensis & 91.8 & J. angkoriensis & 84.6 & NA \\
\hline EM_116 & $\mathbf{L}$ & KX810694 & Nemorimyza posticata & 99.8 & N. posticata & 99.5 & BOLD:AAG9234 \\
\hline EM_U & I & KX810699 & Nemorimyza posticata & 99.3 & N. posticata & 99.4 & BOLD:AAG9234 \\
\hline
\end{tabular}

Note: Leaf-mining taxa are in bold. 
Of the 19 samples we identified as leaf miners, seven could not be assigned to a specific species because the leaf miner barcode library is incomplete. This is neither surprising nor worrisome, as barcode libraries continue to be developed and new leaf miner taxa continue to be discovered (J. Mlynarek, personal observation, 2015). When a method like ours yields a sequence with no barcode match, it has identified an unassigned molecular taxonomic unit, and the population from which those mines were sampled are identified as rewarding for further collection.

We also identified non-leaf-mining taxa from 11 samples: a fungus, one or more whiteflies, and one or more mites. We do not know whether these taxa were associated with the empty mines or just with the leaves. Making this distinction would require additional amplifications from un-mined leaf tissue, which we did not undertake, because our objective was to recover and identify leaf miner DNA. Non-target amplifications are not surprising, given our use of a universal insect primer. Workers wishing to avoid such amplifications can, of course, use more specific primers. However, non-target amplifications can also be seen as a source of additional data. Environmental DNA methods are increasingly being used to assess communities associated with soils, mycorrhizae, or leaves (Taberlet et al. 2012), including bacterial communities of leaves (Redford and Fierer 2009) and fungal communities of leaves (Kembel and Mueller 2014). With appropriate controls and additional primers, our extraction method could likely be applied to compare arthropod and microbial communities associated with herbivore-attacked and unattacked leaves and to examine succession in such communities post-herbivory. It is largely unknown whether non-insect associates of herbivore-damaged leaves contribute to the impact of herbivory (or perhaps mitigate it), but DNA-based identification methods may help make such inferences possible.

Our identification success rate of $19 \%$ may seem modest; indeed, for applications requiring identifications from every mine, collection of mines with larvae still present remains a necessity. However, in many applications (such as monitoring for invasive miners, identification of new pests, deducing leaf miner host ranges, or the detection of cryptic species), all that is required is the detection of the identified leaf miners from some mines. In such cases, our method can provide excellent power because plants under leaf miner attack often have multiple mines per plant (or even per leaf). For example, Godfray (1985) observed on average 24.5 leaf miners per 1000 leaves on a sample of 32 herbaceous plant species, with Rumex crispus having as many as 253 miners per 1000 leaves. Collecting multiple mines at a site, and even from a single plant, should then be straightforward. With a $19 \%$ success rate per mine, very high overall detection success rates can be attained: $65 \%$ given just five mines, $88 \%$ given 10 mines, and $99 \%$ given 20 mines (probability of at least one successful identification for $n$ mines $=1-0.81^{n}$ ). Of course, further methodological development is likely to increase our success rate, further improving power of detection.

\section{Acknowledgements}

We thank JA Addison for support to J-HK and the Fonds de recherche du Québec-Nature et technologies (FRQNT) for support to JJM. Our work was further supported by grants from the Natural Sciences and Engineering Research Council (Canada) to SBH and from the program for Québec/ New Brunswick Cooperation in Advanced Education and Research to SBH and JJM.

\section{Author contributions}

Conceived and designed the study: JJM, SBH. Performed the experiments/collected the data: JJM, J-HK. Analyzed and interpreted the data: JJM, J-HK. Contributed resources: JJM, SBH. Drafted or revised the manuscript: JJM, J-HK, SBH. 


\section{Competing interests}

SBH is currently serving as a Subject Editor for FACETS, but was not involved in review or editorial decisions regarding this manuscript.

\section{Data accessibility statement}

All relevant data are within the paper and available in GenBank. Barcodes are available from https:// www.ncbi.nlm.nih.gov/genbank/; Accession \# KX810676-KX810705.

\section{References}

Abe Y, and Tokumara S. 2008. Displacement in two invasive species of leaf miner fly in different localities. Biological Invasions, 10: 951-953. doi:10.1007/s10530-007-9173-2.

Altschul SF, Gish W, Miller W, Myers EW, and Lipman DJ. 1990. Basic local alignment search tool. Journal of Molecular Biology, 215: 403-410. PMID:2231712. doi:10.1016/S0022-2836(05) $80360-2$.

Auerbach MJ, Connor EF, and Mopper S. 1995. Minor miners and major miners: population dynamics of leaf mining insects. In Population dynamics: new approaches and synthesis. Edited by N Cappuccino and PW Price. Academic Press, San Diego, CA. pp. 83-111.

Benson DA, Karsh-Mizrachi I, Clark K, Lipman DJ, Ostell J, and Sayers EW. 2011. GenBank. Nucleic Acid Research, 40: D48-D53. doi:10.1093/nar/gkr1202.

Condon MA, Scheffer SJ, Lewis ML, Wharton R, Adams DC, and Forbes AA. 2014. Lethal interactions between parasites and prey increase niche diversity in a tropical community. Science, 343: 1240-1244. PMID:24626926. doi:10.1126/science.1245007.

Connor EF, and Taverner MP. 1997. The evolution and adaptive significance of the leaf mining habit. Oikos, 79: 6-25. doi:10.2307/3546085.

Derocles SAP, Evans DM, Nichols PC, Evans SA, and Lunt DH. 2015. Determining plant-leaf miner-parasitoid interactions: a DNA barcode approach. PLoS ONE, 10: e0117872. PMID:25710377. doi:10.1371/journal.pone.0117872.

Folmer O, Black M, Hoeh W, Lutz R, and Vrijenhoek R. 1994. DNA primers for amplification of mitochondrial cytochrome c oxidase subunit I from diverse metazoan invertebrates. Molecular Mariner Biology and Biotechnology, 3: 294-297.

Godfray HCJ. 1985. The absolute abundance of leaf miners on plants of different successional stages. Oikos, 45: 17-25. doi:10.2307/3565217.

Grosberg RK, Levitan DR, and Cameron BB. 1996. Characterization of genetic structure and genealogies using RAPD-PCR markers: a random primer for the novice and nervous. In Molecular zoology: advances, strategies, and protocols. Edited by JD Ferraris and SR Palumbi. Wiley-Liss, New York, NY. pp. 67-100.

Herring EM. 1951. Biology of leaf miners. Springer, Dodrecht, the Netherlands. 420 p.

Hrcek J, Miller S, Quicke DJ, and Smith MA. 2011. Molecular detection of trophic links in a complex insect host-parasitoid food web. Molecular Ecology Resources, 11: 786-794. PMID:21535428. doi:10.1111/j.1755-0998.2011.03016.x. 
Joly S, Davies JT, Archambault A, Bruneau A, Derry A, Kembel SW, et al. 2013. Ecology in the age of DNA barcoding: the resource, the promise and the challenges ahead. Molecular Ecology Resources, 14: 221-232. PMID:24118947. doi:10.1111/1755-0998.12173.

Kembel SW, and Mueller RC. 2014. Plant traits and taxonomy drive host associations in tropical phyllosphere fungal communities. Botany, 92: 303-311. doi:10.1139/cjb-2013-0194.

Mazzanti M, Alessandrini F, Taglabracci A, Wells JD, and Campobasso CP. 2010. DNA degradation and genetic analysis of empty puparia: genetic identification limits in forensic entomology. Forensic Science International, 195: 99-102. PMID:20031351.

Parrella MP, and Keil CB. 1984. Insect pest management: the lesson of Liriomyza. Bullietin of the Entomological Society of America, 30: 22-25. doi:10.1093/besa/30.2.22.

Pons J. 2006. DNA-based identification of preys from non-destructive, total DNA extractions of predators using arthropod universal primers. Molecular Ecology Notes, 6: 623-626. doi:10.1111/ j.1471-8286.2006.01353.x.

R Core Team. 2013. R: A language and environment for statistical computing. R Foundation for Statistical Computing, Vienna, Austria [online]: Available from http://www.r-project.org.

Raimondo F, Ghirardelli LA, Nardini A, and Salleo S. 2003. Impact of the leaf miner Cameraria ohridella on photosynthesis, water relations and hydraulics of Aesculus hippocastanum leaves. Trees, 17: $376-382$.

Ratnasingham S, and Hebert PDN. 2013. A DNA-based registry for all animal species: the barcode index number (BIN) system. PLoS ONE, 8: e66213. PMID:23861743. doi:10.1371/journal. pone.0066213.

Redford AJ, and Fierer N. 2009. Bacterial succession on the leaf surface: a novel system for studying successional dynamics. Microbiological Ecology, 58: 189-198.

Santini A, Lucchini V, Fabbri E, and Randi E. 2007. Ageing and environmental factors affect PCR success in wolf (Canis lupus) excremental DNA samples. Molecular Ecology Notes, 7: 955-961. doi:10.1111/j.1471-8286.2007.01829.x.

Scheffer SJ, and Hawthorne DJ. 2007. Molecular evidence of host-associated genetic divergence in the holly leafminer Phytomyza glabricola (Diptera: Agromyzidae): apparent discordance among marker systems. Molecular Ecology, 16: 2627-2637. PMID:17594435. doi:10.1111/j.1365-294X.2007.03303.x.

Sievers F, Wilm A, Dineen DG, Gibson TJ, Karplus K, Li W, et al. 2011. Fast, scalable generation of high-quality protein multiple sequence alignments using Clustal Omega. Molecular Systems Biology, 7: 539-539. PMID:21988835. doi:10.1038/msb.2011.75.

Spencer KA. 1990. Host specialization in the world Agromyzidae (Diptera). Kluwer Academic Publishers, Dordrecht, the Netherlands. 444 p.

Taberlet P, Coissac E, Hajibabaeh M, and Rieseberg LH. 2012. Environmental DNA. Molecular Ecology, 21: 1789-1793. PMID:22486819. doi:10.1111/j.1365-294X.2012.05542.x.

Zimmermann J, Hajibabaei M, Blackburn DC, Hanken J, Cantin E, Posfai J, et al. 2008. DNA damage in preserved specimens and tissue samples: a molecular assessment. Frontiers in Zoology, 5: 18. PMID:18947416. doi:10.1186/1742-9994-5-18. 